Vol. 8, Issue 12, December 2021

DOI: $10.17148 /$ IARJSET.2021.81216

\title{
Taxes Reforms in India- A Study on Goods and Services Tax
}

\author{
Mr.VinayKumar $\mathrm{C}^{\mathbf{1}}$, Dr.M.kumaraswamy ${ }^{2}$ \\ ${ }^{1}$ Assistant Professor, Sri Venkataramana Swamy College, Bantwal, Dakshinna kannada, Karnataka-574211, India. \\ ${ }^{2}$ Associate professor, University of Mysore, Manasagongotri, Mysuru-06, Karnataka, India.
}

\begin{abstract}
Government of India enforced the Goods and Services Tax in India from September 2017 midnight; it is the big indirect tax reform to the Indian economy having dual tax system with providing contribution to the economy in the form of "Gross Domestic product" in long run. Goods and Services Tax has been introduced to our indirect tax system. Goods and Services Tax (GST) is a comprehensive indirect tax reform in India's history. It is different in way of levy, collection, and administration, where technology driven - Goods and Services Tax Network as front-end for registration application, filing of return, generation of business intelligence and analytics. Reforms in indirect tax will ensure fruitful benefits to various classes' of economy.

Council still exit and making several policies and procedures and also it insist to the Government to enforce. So, it is a good sign still there is a lot of changes will appear in GST policies and procedures soon. GST is affordable and most convenient to both the type of assesses, taxpayers, manufacturers, importers, exporters, sellers, buyers and all other users along with government bodies. In this research paper Authors identify the importance of the tax reforms committee's recommendations, and reviewed the differences of past and present tax reforms in India and finally they procured that the "Goods and services tax is most significant and sufficient tax reforms in indirect tax system of India". Along with this they contributed some suggestions, findings, challenges of GST after enforced in India.
\end{abstract}

Keywords: Tax reforms, GST, Reform committees, Input tax credit, GST model.

\section{INTRODUCTION:}

India has witnessed substantial reforms in the tax system over the past two decades and is on the verge of another major reform initiative which will bring this process to a culmination. As a Progressive and welfare oriented Country India should balance the requirements of direct and indirect taxes in a fair manner. Therefore too much dependence on direct taxes will be repressive but at the same time passing a heavy burden to the general public by way of indirect taxes and will constitute hardships to the common citizen. The objective of this study is to find out the impact of tax systems on the profitability of the organization and growth of the revenue in India and the state of Maharashtra. The past experience in Maharashtra and elsewhere have shown that half baked reforms in the name of VAT have done more harm than good in evolving a tax system required for a competitive environment. It is important to assess how this scenario changes from Sales tax to VAT and VAT to GST.

The present GST has been changing the whole scenario of current indirect tax system. It is considered as biggest tax reform since 1947. Currently, in India complicated indirect tax system is followed with imbrications of taxes imposed by union and states separately. GST has been unify all the indirect taxes under an umbrella and will create a smooth national market. Experts say that GST is helping the economy to grow in more efficient manner by improving the tax collection as it will disrupt all the tax barriers between states and integrate country via single tax rate. GST was first introduced by France in 1954 and now it is followed in more than 150 countries. Most of the countries followed unified GST while some countries like Brazil, Canada follow a dual GST system where tax is imposed by central and state both. In India also dual system of GST it includes CGST and SGST.

Tax reform committees gave a contribution to the development of tax reforms in India, after independence, Government of India was appointed John Matthai and his team to review tax structure in India. They mainly recommended that widening tax structure in centre as well as state level for the purpose of financing development outlay and reducing large inequalities of income and also recommended for providing tax incentives. K.N. Wanchoo recommended that measures for detection of black money, evaluations of tax evasion and decreasing tax arrears etc. L.K Jha reform committee made some recommendation during the year 1983, they were as follows: Employers should be permitted to deduct tax at the paying the income including salary.

Raja J Chelliah tax reform committee constituted during the year 1991. Here under this recommendation reviews that, Taxes on local production should be fully converted in to value added tax, Wealth tax should be levied only on 
unproductive assets, exemptions and concessions should be removed in both direct and indirect taxes, corporate tax rate should be reduced up to 40 percent, three tier income structure should be introduced etc. Vijay Kelkar submitted its report in 2002, where rationalize and simplify direct taxes, improvement in taxpayers service are the major issues. Under that report committee recommended mainly, Government should introduce national tax information network on a BOT basis, setup structure for Electronic Data Interchange for the major departments, Abolish Minimum Alternate Tax. Implementation of GST is the outcome of biggest tax reforms and it shows a road map to the implementation of Goods and services tax in India. GST has been so far biggest reforms initiated by the Government of India and also it is a major millstone in Indirect Tax Reforms. Goods and Services Tax move was started in the beginning of 2007 onwards and finally, it was implemented September 2017 from midnight.

\section{REVIEW OF LITERATURE:}

The researcher paper has carried out a review of exhaustive literature relating to the Indian tax system, taxes in India, and tax reforms committees in Indian at both central and state level. An attempt has been made to summaries the important studies and works keeping in mind the relevance of the present Paper. Literature survey is used to secure a strong base to this research on tax reforms and GST.

Malini Chakravarthy (2016): in her paper stated that “ India's Tax system : increasing progressively" GST would help to simplify and rationalize the Indian tax system and increase tax compliance and also insist that the Government should take some steps to increase the tax revenues, so that it would help to increase overall economic development of the country.

Shefali and Dani(2016) in their research paper on "An impact of GST on Indian Economy", they highlighted that GST appears to be unfavorable for telecommunication, and India is still in the budding state as far as internet connectivity in concerned. So, country as required a strong IT network for effective GST structure in India. Finally, authors concluded that GST will help to remove inefficiencies created by the exiting current taxation system.

B Mitra priya,in her paper "GST-A Game Changer", focus on impact on Tax incidence where GST rate may increase up to $18 \%$ at normal rate, on all major Telecommunication industry, Banking sector, consumer goods and auto mobile industry. Finally, author hopes that GST has the potential to boost GDP over a period of time by extending the tax bases.

Sakharam Mujalde, Avi Vani, In their research paper "Goods and service Tax and its outcome in India, stated that, Input tax credit and compensation to states, under the new tax system over period of time and finally, they persist that The GST impact on growth will be negative in short run but positive in later, as per the experiences of the developed countries in the global tax system.

Monika Sehrawat, Her research paper on "GST in India: A key Tax Reform", Mainly focus on concept of GST, Timeline of GST Implementation in India, finally author desires that GST will give India a world class tax system by grabbing different treatment to manufacturing and service sector.

Aurobinda panda and Atul patel, Research paper "The impact of GST on Indian Tax Scene", Where they stated with a brief description of the historical scenario of Indian taxation and its tax structure. And also they suggest that under impact of small enterprises specified goods are allowed exemption of excise up to Rs. 1.5 crores. These unites may be required to register for payment of GST, may see this as an additional cost. Finally they conclude that while GST serves to be beneficial set up for the industry and consumer, it would lead to increase in revenue to Government.

\section{OBJECTIVES OF THE PAPER:}

Study the present and past indirect taxes systems in India.

To analyze the various tax reforms committee's recommendations.

To study the contribution of Goods and Services Tax in Indian tax revenue

To identified the challenges and benefits of Goods and Services Tax in India.

To make suggestion to strengthen the GST in Indian tax system.

\section{RESEARCH PROBLEM:}

India has been retuning tax system to bring the comprehensive tax structure in levy, collection and administration totally. To assess the effectiveness of the GST tax reforms after implementation of Goods and Services Tax, it is still in infant stage. The paper intends to cognize the past and current tax reforms committees in India, to study the overall impact of Goods and Services Tax in India system and also to identify the further changes required in tax reforms. 
Vol. 8, Issue 12, December 2021

DOI: $10.17148 /$ IARJSET.2021.81216

\section{RESEARCH METHODOLOGY:}

This research paper is descriptive in nature and it is based on secondary data An effort is made to collect actual information about " Taxes Reforms in India: A study on Goods and services Tax" for this purpose published reports, statistical figures, are collected from books, Magazines, published periodicals, Gazettes, journals in India, research papers of both national and international standards.

5.1 Backgrounds of Goods and services Tax: GST provides lot more incentives to all the sectors. It includes all manufacturing sectors, agriculture sectors and service sectors in the country, and invites corporate people to startup their business and benefiting to the common people by reducing cascading tax effect no doubt goods and Services Tax may provide different treatments to manufacturing and services sector in next days. In Indian context, GST model have four components they are;

i.IGST - Integrated goods and services tax levied by central level.

ii.CGST - Central goods and services tax levied by central level.

iii.SGST - State goods and services tax levied by state level

iv.UGST- Union Territory Goods and services tax levied by Union territory level

GST slabs had been set at $0 \%, 5 \%, 12 \%, 18 \%$, and $28 \%$ respectively for a different goods and services. Hope this consecutive changes will bring positive energy to Indian economy and we expect GST will brings transparency, efficiency and corruption free tax administration in the society.

5.2 GST Council: Goods and services Tax council incorporated under Indian constitution article 279A. Here 2/3rd representatives in council are from states, $1 / 3^{\text {rd }}$ from union. Decision is made by $3 / 4^{\text {th }}$ majority of the votes cast and quorum of council is 50 percent. And it also works as a Dispute Settlement Authority for Goods and Services Tax. Union government will provide compensation to the states up to 5 years for the revenue losses arising out of GST implementation and it further extended that for first three years 100 percent compensation and in next two years it reduced to 75 percent, 50 percent respectively. More ever GST council still exit and provide lot of policies and procedures to the government and enforce them to incorporate.

5.3 Study about Present and past indirect taxes systems in India: There are some Structural differences between GST scenario and past taxes scenario; GST includes duel tax system with both central and state GST, levied on same base on all the goods and services except petroleum, high speed Diesel, Natural gas and motor spirit. Where in past tax scenario, Central Taxes includes Excise duty, Central sales tax, Surcharge and cess. State Taxes includes VAT, Purchase tax, Luxury Tax, Entertainment Tax, and Tax on Lottery, Surcharge, and cess. Under the Goods and services tax it's taxable at the place of consumption, where in early indirect taxes systems taxable at the place of manufacture /sale of goods, rendering of services. The following structural difference is identified in the Indirect taxes systems of India and mentioned below and is as follows.

Differences between the present and the Past Indirect Taxes systems in India.

\begin{tabular}{|l|l|l|}
\hline Structural difference & GST scenario & Early tax scenario \\
\hline Service tax & Subsumed under SGST & $\begin{array}{l}\text { Charged by centre under } \\
\text { finance oct } \\
\text { Payment/provision basis }\end{array}$ \\
\hline Cascading Effect & $\begin{array}{l}\text { Credit available on the full } \\
\text { amount of taxes up to retailer }\end{array}$ & $\begin{array}{l}\text { Credit available for excise and } \\
\text { service tax }\end{array}$ \\
\hline Excise Duty & $\begin{array}{l}\text { Replaced by CGST up to } \\
\text { retail level }\end{array}$ & $\begin{array}{l}\text { Charged up to the point of } \\
\text { manufacturing }\end{array}$ \\
\hline Basic Custom Duty & $\begin{array}{l}\text { In Case of Import, Taxed by } \\
\text { Centre under separate Act }\end{array}$ & \multicolumn{1}{|c|}{ No Change } \\
\hline Countervailing Duty & Subsumed under CGST & $\begin{array}{l}\text { In Case of Import, Taxed by } \\
\text { Centre under separate Act }\end{array}$ \\
\hline Central Sales Tax & Subsumed under IGST & $\begin{array}{l}\text { 2 percent on interstate transfers } \\
\text { against C forms, full rate up to } \\
14.5 \text { percent }\end{array}$ \\
\hline Entry Tax & Subsumed under CGST & $\begin{array}{l}\text { Charged by selected states for } \\
\text { interstate transfer }\end{array}$ \\
\hline
\end{tabular}


International Advanced Research Journal in Science, Engineering and Technology

Vol. 8, Issue 12, December 2021

DOI: $10.17148 /$ IARJSET.2021.81216

\begin{tabular}{|l|l|l|}
\hline $\begin{array}{l}\text { Tax on Export of } \\
\text { goods and service }\end{array}$ & Zero rated & Exempted \\
\hline $\begin{array}{l}\text { Tax on interstate } \\
\begin{array}{l}\text { Transfer of goods to } \\
\text { Branch }\end{array}\end{array}$ & Subsumed under IGST & Exempt against form F \\
\hline $\begin{array}{l}\text { Tax on Transfer of } \\
\text { goods to Branch within } \\
\text { state }\end{array}$ & $\begin{array}{l}\text { Subsumed under CGST and } \\
\text { SGST }\end{array}$ & Exempted \\
\hline
\end{tabular}

Source: primary data

The above differences also in case of threshold Limit, Levy of Tax on NGO's, and on other Government bodies, Exemption on Excise free zone etc. in case of tax rates on goods and services still making changes by GST council anyway these are the major structural difference between past and present indirect taxes systems.

\section{MAJOR CHALLENGES OF GST:}

are as follows;

After introduction of Goods and services Tax in India as many as hurdles the economy is facing they

1. Conducting regular timely meeting for retune goods and services lists and its rate of tax for FMCG, consumer durables and hand loom industry and luxury durable goods is the major issue in GST council.

2. The present GST system is completely paperless and online software administration to ensure tax avoidance and evasion in the indirect tax system, but to implement without proper preparation both from the tax authorities and dealers is the big challenge.

3. Especially in new GST most of the unorganized sectors are excluded. So, it's one of the challenges to GST council to add these sectors under GST to avoid tax avoidance and tax evasion to increase the tax base in indirect tax system.

4. It is a challenge to the Government to identify the problems and to overcome slow growth rate of GDP, whether it is because of demonetization of high value of currency or implementation GST both are confusion in minds of experts and peoples.

5. In favor of Consumer durable products GST rate reduced up to zero percent and few Luxury durable goods set at 12 percent, 18 percent respectively. GST council promised recently still some other durable goods rate also reducing in upcoming days. So, it is really benefited to the low salaried people but it is big challenge for the both center and state government in rising expected revue in long run. 


\section{International Advanced Research Journal in Science, Engineering and Technology}

\section{Vol. 8, Issue 12, December 2021}

\section{DOI: $10.17148 /$ IARJSET.2021.81216}

6. The promise made by the center government to reimburse the revenue loss happened to the states that should be reducing soon, and in few months later states are comes to the right track and get the huge revenue shortly. As per new information central government after implementation of GST is big challenge not only reimburse but, also to get reimbursed amount by the state government in timely without affecting their financial commitments.

\section{SUGGESTIONS:}

The researcher feels that, implementation of GST in Indian tax has been big tax reforms in indirect tax structure, this kind of tax reforms developing in the big country like India, is still they required some more reforms and to improve the existing tax system. So, the authors feels the suggestions are timely consider:

1) GST will ensure lot of revenue to the both center and state government by increasing the tax base in indirect taxes. So, if government wants to increase their revenue better to provide proper education to dealers, tax authorities and finally to the consumers.

2) Here authors highly recommending towards Goods and services tax rates. That, instead of Increase or decrease the GST rates thing about how to increase the revenue of the government. So, it may helps the economic development of the country, for a long period Government and respected the departments should put proper steps to increase indirect tax revenues of the country. That means still effective and efficient administration should have required in the field of tax collection, e return, e payment, e filling etc.

3) The GST council should decrease levy on Entertainment and on the Luxury goods up to 20 percent. Because, Most of the people consuming this type of products and services regularly. So, it's positively impact on the revenue of country. That means more and more people come under this levy and finally the revenue of the country will increase. 4) Authors recommended that, for the effective and efficient administration in respected the concerned department of GST requires staffs. So, Government should take essential steps to have new force by making new recruitment instead of outsourcing.

5) Authors recommended that, People looking for custom duty should be part of GST. So, GST council should take proper decisions without making any discrimination among the states revenue. And as soon as custom duty should be under GST for the welfare of the tax payers.

6) Authors recommended that, GST council is responsible to provide policies, procedures, guidelines and regulations within a "time constraint" it may helps to reduce the loss on tax revenue occurred to the states and ensure good tax system for the economy.

7) The existing both indirect and direct tax requires to reforms Common tax code and Direct tax code to make single tax system in India.

\section{CONCLUSION:}

The slogan of the GST "one Nation one Tax", it may become the tagline of the goods and services tax in India. Goods and Services Tax is a comprehensive, multistage, consumption based, Information technological driven indirect tax system. In this study, effort has been made to explain that, Goods and Services Tax provides various benefits and poses various problems to different class like Economy, business and consumers, which is based on their own ambit and perception. In economic perspective, GST will widen taxpayer base, which would increase tax revenue and help in creation of employment opportunities and ensure equal wealth distribution across India. The researchers observed that the "Goods and services tax is most significant and sufficient tax reforms in indirect tax system in India.

GST may be the old concept to the world. But, For India, GST is just a baby, which we cannot clearly specific its milestones. In order to take such baby in an efficient and effective way; more research is needed on every state and every class of industry, price of goods and services, consumption level of people and other related aspects of economy. It is hoped that, such comprehensive technological driven indirect tax system will catch up all commercial transactions and that would lead to transparency of businesses across India and finally, GST will be success with 'Win-win situation'. GST by optimizing cost, time and resources, ensures a healthy competitive environment, help in easy availability of external funds. Multi-state registrations, tax compliances, increase in income tax liability maps either faces of GST. In consumer perspective, along with availability of various goods and services, it would decrease the price of same. But, due to lack of strong anti-profiteering measures, price of goods and services are still in upward direction to ensure all benefits it requires further tax reforms.

\section{REFERENCES:}

i. Sakharam Mujalde (2017) "GST and its outcome in india, journal of madya Pradesh economic association vol 27 feb 2017 
International Advanced Research Journal in Science, Engineering and Technology

Vol. 8, Issue 12, December 2021

\section{DOI: 10.17148/IARJSET.2021.81216}

ii. Alpna yadav(2017) “Impact of GST on Indian economy”,SSRG international Journal of Economics and Management studies vol 2017

iii. Acharya Shankar,(2005): “ Thirty years of Tax Reforms in India”. Economic and Political Weekly, vol 40,pp 2061-2069.

iv. Girish Garg.(2014) :"Basic concepts and Features of Goods and Service Tax in India". International Journal of Scientific Research and Management (IJSRM) vol: 21, pages 542-549, ISSN 2321-3418

v. Monika Sehrawat.(2015): "GST in India: A key Tax Reform”. International journal of Research Granthaalayah Impact factor 2.035, pp 23943629

vi. Jaspreet Kaur, (2016): “ Goods and Service Tax and its Impact”. International Journal of Applied Research (IJAR) 2(8)-385-387, Impact factor 5.2 .

vii. Malini Chakravarthy(2016): “India’s Tax system : increasing progressivity’. Yojana nov 2016 